Article

\title{
Genotypic and Phenotypic Evaluation of Biofilm Production and Antimicrobial Resistance in Staphylococcus aureus Isolated from Milk, North West Province, South Africa
}

\author{
Marie Ebob Agbortabot Bissong ${ }^{1,2, *(\mathbb{C})}$ and Collins Njie Ateba ${ }^{1,3}$ \\ 1 Antibiotic Resistance and Phage Biocontrol Research Group (AREPHABREG), Department of Microbiology, \\ School of Biological Sciences, North-West University-Mafikeng Campus, Private Bag X2046, \\ Mmabatho 2735, South Africa; collins.ateba@nwu.ac.za \\ 2 Department of Biomedical Science, University of Bamenda, Bambili P. O. Box 39, Cameroon \\ 3 Food Security and Safety Niche Area, Faculty of Natural and Agricultural Sciences, North-West University, \\ Mmabatho, Mafikeng 2735, South Africa \\ * Correspondence: mabissong@yahoo.com; Tel.: +237-67-530-1641
}

Received: 23 February 2020; Accepted: 30 March 2020; Published: 2 April 2020

check for updates

\begin{abstract}
Background: Biofilm formation in S. aureus may reduce the rate of penetration of antibiotics, thereby complicating treatment of infections caused by these bacteria. The aim of this study was to correlate biofilm-forming potentials, antimicrobial resistance, and genes in S. aureus isolates. Methods: A total of 64 milk samples were analysed, and 77 S. aureus were isolated. Results: Seventy (90.9\%) isolates were biofilm producers. The ica biofilm-forming genes were detected among $75.3 \%$ of the isolates, with ica A being the most prevalent $(49,63.6 \%)$. The icaB gene was significantly $(P=0.027)$ higher in isolates with strong biofilm formation potentials. High resistance $(60-90 \%)$ of the isolates was observed against ceftriaxone, vancomycin, and penicillin, and $25(32.5 \%)$ of S. aureus showed multidrug resistance (MDR) to at least three antibiotics. Five resistance genes, namely blaZ $(29,37.7 \%)$, $\operatorname{vanC}(29,37.7 \%)$, tetK $(24,31.2 \%)$, tetL $(21,27.3 \%)$, and $m s r A / B(16,20.8 \%)$ were detected. Most MDR phenotypes possessed at least one resistance gene alongside the biofilm genes. However, no distinct pattern was identified among the resistance and biofilm phenotypes. Conclusions: The high frequency of potentially pathogenic MDR S. aureus in milk samples intended for human consumption, demonstrates the public health relevance of this pathogen in the region.
\end{abstract}

Keywords: Staphylococcus aureus; biofilm; antimicrobial resistance; genes; milk; public health

\section{Introduction}

Staphylococcus aureus is a Gram-positive bacterium that colonizes the skin, anterior nares, and mucous membranes of a variety of animal species [1,2]. They are facultative pathogenic organisms in both animals and humans and therefore cause a variety of diseases in their hosts [3]. S. aureus causes mastitis in dairy cattle, and it is known to be one of the most important etiological agents of intra-mammary infections in ruminants [4]. As a result, S. aureus infections present major economic and severe public health challenges to the milk and dairy sectors [4]. Infected mammary glands are the main reservoir for infection; however, the contamination of dairy products can occur anywhere in the food chain, especially during milking procedures [3]. The consumption of contaminated milk may present with serious health hazards to humans [4]. The public health significance of $S$. aureus is amplified by the fact that in humans, this bacterium is associated with both nosocomial and community-acquired infections [5]. 
The potential of $S$. aureus to cause disease is based on its ability to produce a wide variety of virulence factors that contribute to bacterial invasion [6]. These include factors that are responsible for the attachment, adherence, and biofilm formation [6]. Biofilm formation has been reported to enhance the virulence of bacterial species, including S. aureus [6,7]. Biofilm formation in S. aureus involves three major stages: attachment, maturation, and dispersion of bacterial cells [7]. The fundamental step in S. aureus biofilm formation is initial attachment, which is accomplished by the expression of different Microbial Surface Components Recognizing Adhesive Matrix Molecules (MSCRAMMs) [7]. S. aureus initially adheres to each other and then widen to structurally dynamic biofilm structures during the later phases of adherence. The maturation of the biofilm matrix into multi-layered patterns is initiated by the polysaccharide intercellular adhesin (PIA), synthesized from $\beta$-1, 6- linked N-acetyld-glucosamines (PNAG) [8]. The synthesis of PIA is mediated by the intercellular adhesin (ica) locus, which comprises four core genes, namely $i c a A, i c a D$, icaB, and $i c a C$, as well as a regulatory gene, (icaR) [9]. These genes encode the corresponding proteins ICAA, ICAD, ICAB, and ICAC. The production of slime is facilitated by the coexpression of $i c a A$ and icaD genes [10]. The role of icaB is not fully elucidated, but icaC acts as a receptor for polysaccharides [9]. It has been shown that strains harbouring the icaADBC cluster are potential biofilm producers [10]. In addition, the biofilm-associated protein (Bap) is vital for the primary attachment of $S$. aureus and biofilm formation [11,12].

Antimicrobial resistance in $S$. aureus is a major veterinary, as well as public, health concern worldwide since multi-resistant strains present a severe challenge to effective treatment [13-15]. Antibiotics are extensively used in food-animal production, and this has resulted in the rise of antibiotic-resistant S. aureus in food animals and foods of animal origin [16]. Antimicrobial resistance in methicillin resistant $S$. aureus (MRSA) strains is due to the production of penicillin-binding protein 2a (PBP2a), which is encoded by the mecA gene located on the mobile element of the staphylococcal chromosome cassette mec (SCCmec) [17]. The presence of these genes in MRSA make them resistant to multiple antibiotics, particularly all ß-lactam antibiotics. It has been suggested that cattle may serve as a source of MDR and new MRSA strains in humans [18]. Therefore, colonization of dairy cattle with antimicrobial-resistant $S$. aureus impacts milk production and may additionally represent an infection hazard to people who work in close contact with cows or consume raw milk [18].

The colonization of dairy cattle and subsequent contamination of raw milk by pathogenic S. aureus remains an important issue for both the dairy producers and the public health sector [19]. The formation of biofilm reduces the rate of penetration of antibiotics, thereby complicating treatment of infections caused by these bacteria $[6,19,20]$. Colonization impacts negatively on milk production and may additionally represent an infection hazard to people who work in close contact with cows or consume raw milk [18]. The food-animal production industry in South Africa is fast growing in order to meet the demand of meat supply to the increasing population $[13,16]$. Most of the dairy farms located in the Mafikeng area are small-scale farms owned by independent farmers who usually supply fresh milk to processing plants, as well as to the local communities for direct consumption. In such cases, if proper hygienic practices are not observed during the milking process, milk intended for human consumption may become contaminated and eventually pose serious health problems to the consumers. This highlights the importance of the screening of milk and other animal products, for the presence of pathogenic biofilm producing S. aureus.

In South Africa, S. aureus has been detected from varied sources, including bovine milk [21-23], pigs [24], beach water [25], and human samples [23,26,27]. However, studies reporting the biofilm-producing capabilities of $S$. aureus in Southern Africa are limited [27]. Naicker et al reported strong biofilm production among a large proportion (57\%) of clinically invasive $S$. aureus isolates belonging to the spa clonal complex 064 [27]. The present study is aimed at expanding on previous investigations in the area, by determining the genotypic and phenotypic characteristics of biofilm producing and antimicrobial-resistant $S$. aureus isolated from milk. 


\section{Results}

\subsection{Isolation of S. aureus}

S. aureus was isolated from all the unpasteurized milk samples, and only 7 out of 24 (29.2\%) pasteurized milk samples showed growth. A total of $77 \mathrm{~S}$. aureus were isolated from the milk samples, out of which 7 (9.1\%) and 70 (90.9\%) isolates were from pasteurized and unpasteurized milk, respectively $(P<0.05)$. The distribution of isolates with respect to the study location presented in Table 1 revealed that more of the isolates $(33,42.9 \%)$ were from Mafikeng, while only two isolates $(2.5 \%)$ were from Zeerust.

Table 1. Distribution of biofilm formation with respect to study location.

\begin{tabular}{llllllll}
\hline \multirow{2}{*}{$\begin{array}{c}\text { Proportion of Isolates in the Different } \\
\text { Biofilm Forming Categories }\end{array}$} & \multicolumn{5}{c}{ Location } & \multirow{2}{*}{ Total } & \multirow{2}{*}{$\boldsymbol{P}$-Value } \\
\cline { 3 - 7 } & Mafikeng & Rooidepand & Rooigrond & Zeerust & & \\
\hline \multirow{2}{*}{ Biofilm } & Moderate & 3 & 1 & 0 & 0 & 4 & \\
\multirow{2}{*}{ Formation } & None & 3 & 1 & 2 & 1 & 7 & 0.526 \\
& Strong & 27 & 13 & 25 & 1 & 66 & \\
\hline \multicolumn{2}{r}{} & $33(42.9)$ & $15(19.5)$ & $27(35.1)$ & $2(2.5)$ & 77 \\
\hline
\end{tabular}

\subsection{Phenotypic Biofilm Production}

Out of 77 S. aureus isolates tested for phenotypic biofilm formation, 70 (90.9\%) were biofilm producers, while seven $(9.1 \%)$ were non-biofilm producers. The biofilm producers were further classified as "Strong" (66, 94.3\%), "Moderate" (4, 5.7\%), and "Weak" (0, 0.0\%) producers. The distribution of biofilm formation in $S$. aureus strains isolated from the different study location did not show any significant difference $(P=0.526)$.

\subsection{Detection of Biofilm Genes}

Five biofilm genes were detected among $S$. aureus isolates, and the electrophoretic patterns of the ica genes are presented in Figure 1. The ica genes were detected in 58 (75.3\%) of the isolates, among which icaA was the most prevalent (49,63.6\%), followed by icaB $(48,62.3 \%)$, icaD $(43,55.8 \%)$ and icaC $(30,38.9 \%)$. On the other hand, the bap gene showed the lowest rate of detection $(12,15.6 \%)$.

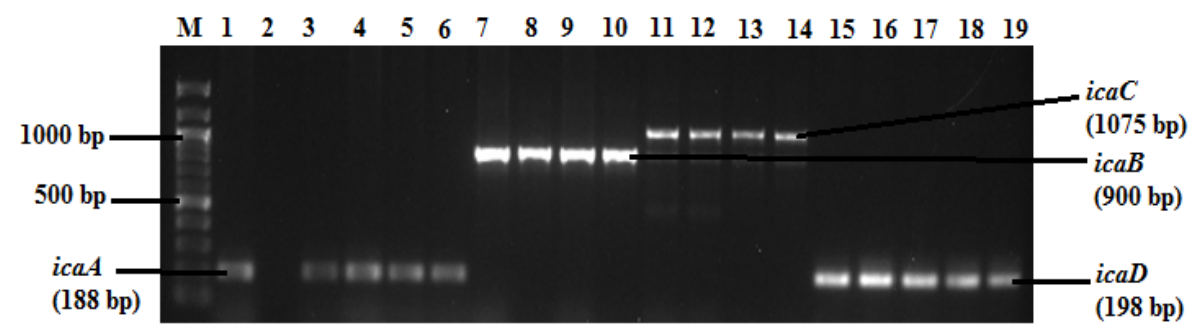

Figure 1. Agarose $(1 \% \mathrm{w} / \mathrm{v})$ gel of the ica gene products of $S$. aureus isolates. Lane $\mathrm{M}=\mathrm{DNA}$ marker (100 base pairs DNA Ladder); Lane $1=i c a A$ amplicon of positive control (S. aureus ATCC 25923); Lane 2 = icaA amplicon of negative control (E. coli ATCC 25922); Lanes 3-6 = icaA amplicons; Lane $10=i c a B$ amplicons; Lanes 11-14 = icaC amplicons; Lanes 15-19 = icaD amplicons.

\subsection{Cluster Analysis of Biofilm Genes in S. aureus Isolated from Milk}

Several genotypes with various biofilm gene combinations were observed in a hierarchical cluster analysis, as presented in Figure 2. However, the most prevalent (27, 31.5\%) was "Genotype A1a", which comprises all the ica genes (icaA, icaB, icaC, and icaD). Interestingly, the bap gene occurred independently of the ica genes in 8 out of $12(66.7 \%)$ S. aureus isolates. Furthermore, 11 out of 77 (14.3\%) S. aureus isolates did not present with any of the biofilm genes. Only 4 out of 77 (5.1\%) S. aureus isolates possessed both icaA and icaD genes (Genotype B3b). 


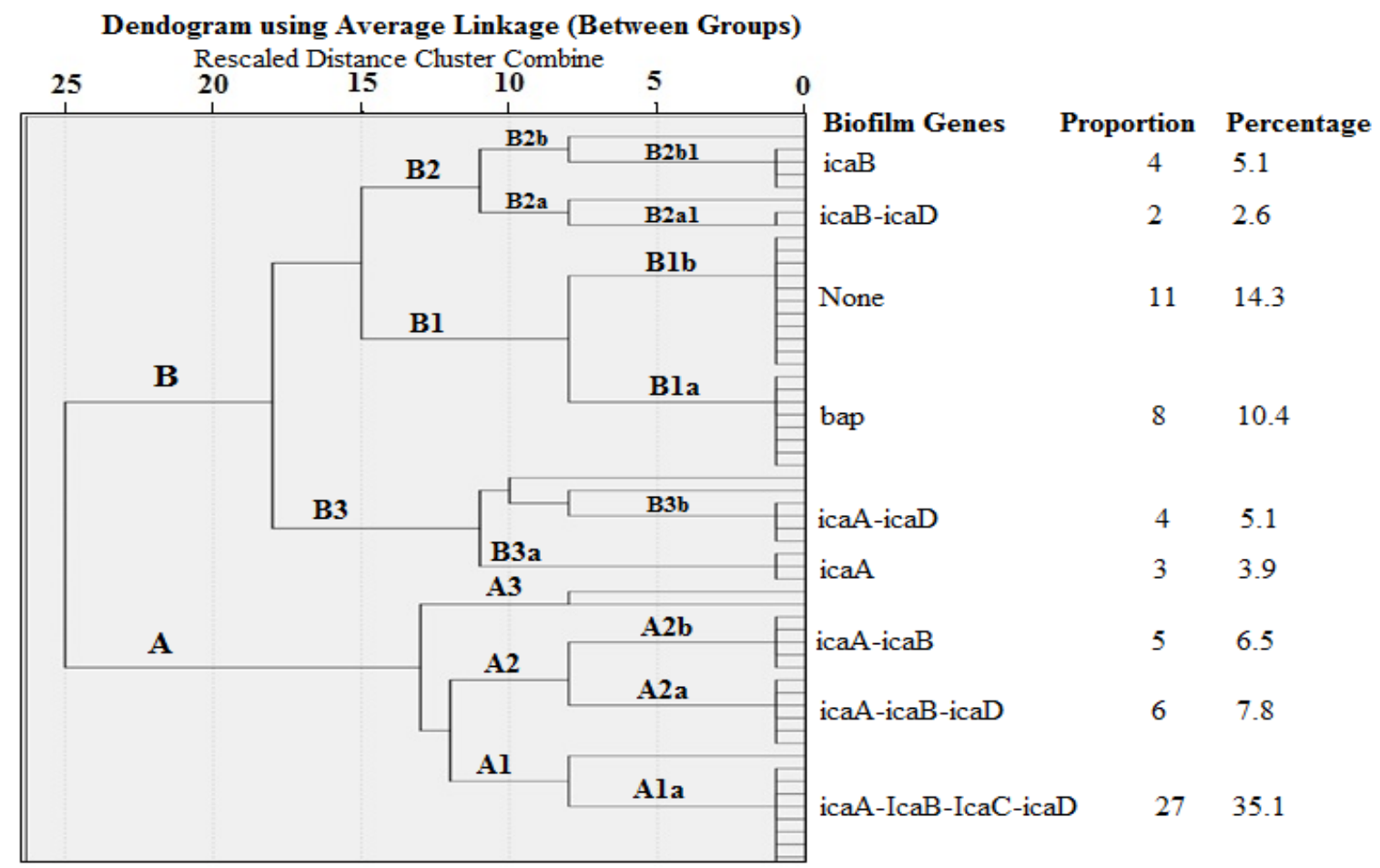

Figure 2. A dendrogram showing the clustering of biofilm genes based on $\mathrm{OD}_{680}$ of $S$. aureus isolates (the dendrogram was obtained by using the unweighted paired group method).

\subsection{Relationship between Biofilm Formation and Biofilm Genes in S. aureus Isolates}

The distribution of various biofilm genes with respect to biofilm formation in $S$. aureus isolates is presented in Table 2. Although there was no significant difference $(P>0.05)$ in the occurrence of the iacA, icaC, iacD, and bap among various categories of biofilm-producing $S$. aureus, these genes were generally more common in biofilm-producing isolates than in non-biofilm-producing isolates. On the other hand, the frequency of $i c a B$ was significantly higher in "strong biofilm producers" $(44,69.7 \%)$ than in "Moderate" $(2,50.0 \%)$ and "None" producers $(0,0.0 \%)$.

Table 2. Relationship between biofilm formation and biofilm genes in S. aureus isolates.

\begin{tabular}{llllll}
\hline \multirow{2}{*}{ Biofilm Formation } & \multicolumn{5}{c}{ Number (\%) of Isolates Having the Biofilm Gene } \\
\cline { 2 - 5 } & $\boldsymbol{i c a A}$ & $\boldsymbol{i c a B}$ & $\boldsymbol{i c a C}$ & icaD & bap \\
\hline None $(n=7)$ & $4(57.1)$ & $0(0.0)$ & $0(0.0)$ & $3(42.9)$ & $1(14.3)$ \\
Moderate $(n=4)$ & $3(75.0)$ & $2(50)$ & $3(75.0)$ & $4(100)$ & $1(25)$ \\
Strong $(n=66)$ & $42(63.6)$ & $46(69.7)$ & $27(40.9)$ & $36(54.5)$ & $10(15.1)$ \\
Total $(n=77)$ & $49(63.6)$ & $48(62.3)$ & $30(38.9)$ & $43(55.8)$ & $12(15.6)$ \\
$P$-value & 0.777 & 0.027 & 0.259 & 0.674 & 0.084 \\
\hline
\end{tabular}

\subsection{Antibiotic Susceptibility Test (AST)}

All 77 S. aureus isolates were resistant to at least one of the 13 antibiotics. High resistance (60-90\%) was observed against ceftriaxone (87\%), followed by vancomycin $(83.1 \%)$ and penicillin G $(77.9 \%)$ (Figure 3). Other members of the class penicillin (amoxicillin, ampicillin, and oxacillin) showed similar resistance patterns to penicillin G. In contrast, low resistance was observed against ciprofloxacin (11.7\%), chloramphenicol $(14.3 \%)$, and sulfamethoxazole-trimethoprim (14.3\%). Meanwhile, twenty-five $(32.5 \%)$ of the $S$. aureus isolates showed multidrug resistance (MDR) to at least three antibiotics of different classes. 


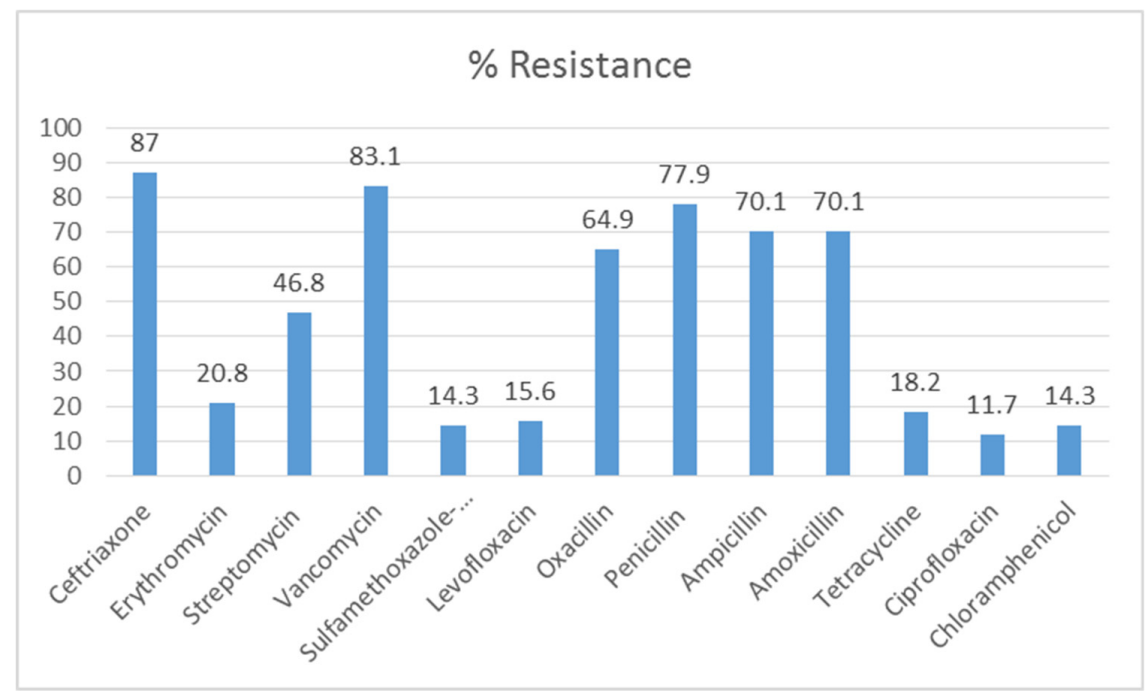

Figure 3. Antimicrobial resistance of S. aureus isolates.

A total of 30 were selected to be tested for inducible clindamycin resistance (D test). None of the isolates showed inducible clindamycin resistance. However, three phenotypes were observed: Phenotype " $R$ " $(9,30 \%)$ which were resistant to both erythromycin and clindamycin and are indicative of constitutive clindamycin resistance; Phenotype " $\mathrm{I}$ " $(8,26.7 \%)$, which showed intermediate resistance to clindamycin but were susceptible to erythromycin; and Phenotype "S" (13,43.3\%), which were sensitive to both erythromycin and clindamycin.

Five resistance genes were detected in the isolates, with the following frequencies: blaZ $(29,37.7 \%)$, vanB $(29,37.7 \%)$, tetK $(24,31.2 \%)$, tetL $(21,27.3 \%)$, and $m s r A / B(16,20.8 \%)$. On the other hand, van $A$ and $m e f A$ genes were not detected among the isolates. The distribution of the resistance genes with respect to phenotypic resistance to the corresponding antibiotic was not statistically significant $(P>0.05)$.

\subsection{Relationship between Penicillin Diameter, blaZ Genes, and Beta Lactamase Production}

Figure 4 shows the Boxplot of penicillin diameter (PD) of blaZ-negative and blaZ-positive S. aureus isolates. Although the median PDs of blaZ-negative and blaZ-positive isolates are slightly similar, the interquartile range of blaZ-negative isolates is higher than that of blaZ-positive isolates. In addition, the Mann-Whitney U Test revealed that the PD of blaZ-negative isolates (Mean Rank $=40.34$ ) was higher than that of blaZ-positive isolates (Mean Rank $=36.78$ ), though this difference was not significant $(U=631.5, P=0.497)$.

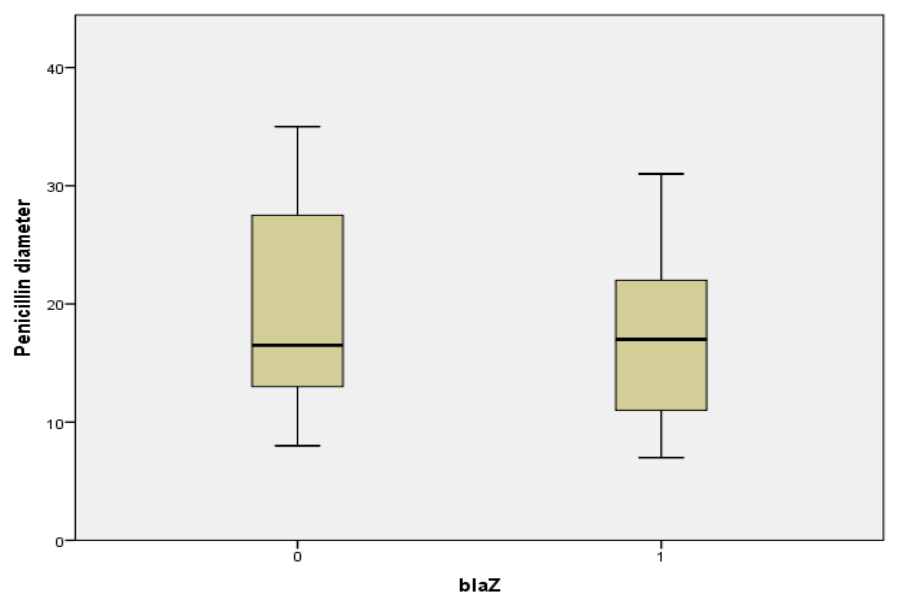

Figure 4. A Boxplot of penicillin diameter and blaZ gene ( $0=$ blaZ-negative, $1=$ blaZ-positive). 
A total of $56(72.7 \%)$ of the isolates were positive for beta lactamase production (zone-edge test). There was a relationship between blaZ and beta lactamase production $\left(\chi^{2}=4.262, p=0.039\right)$. More $(25 / 29,86.2 \%)$ of the isolates that are positive for the blaZ gene also expressed beta lactamase production (Table 3).

Table 3. Correlation between blaZ genes and beta lactamase production.

\begin{tabular}{lllll}
\hline \multirow{2}{*}{ Phenotypic Characteristic } & \multicolumn{2}{l}{ blaZ Gene $(\%$ *) } & \multirow{2}{*}{ Total } \\
\cline { 3 - 5 } & & Negative & Positive & \\
\hline Beta Lactamase & Negative & $17(35.4)$ & $4(13.8)$ & 21 \\
Production & Positive & $31(64.6)$ & $25(86.2)$ & 56 \\
\hline Total & 48 & 29 & 77 \\
\hline \multicolumn{5}{r}{} \\
\end{tabular}

\subsection{Profiling of Biofilm Formation and Resistance Patterns of MDR S. aureus Isolates}

The resistance and biofilm profiles of the $25 \mathrm{MDR}$ isolates were assessed, and it was observed that the majority $(11 /, 44 \%)$ belong to the cef-van-oxa phenotype, which showed multidrug resistance to ceftriaxone, vancomycin, and oxacillin (including other penicillins) (Table 4). Most of the MDR phenotypes also possessed at least one of the resistance genes, alongside the biofilm genes. Although no distinct pattern was identified among the resistance and biofilm phenotypes, most strains that showed moderate or no biofilm production did not have the ica genes (Table 4).

Table 4. Antimicrobial resistance and biofilm profile of MDR S. aureus isolates.

\begin{tabular}{|c|c|c|c|c|c|c|c|c|c|c|c|c|}
\hline \multirow{3}{*}{$\begin{array}{l}\text { MDR } \\
\text { Isolate }\end{array}$} & \multirow{3}{*}{ Resistance Phenotype } & \multirow{3}{*}{$\begin{array}{l}\text { Biofilm } \\
\text { Production }\end{array}$} & \multicolumn{5}{|c|}{ Resistance Genes } & \multicolumn{5}{|c|}{ Biofilm Genes } \\
\hline & & & \multirow{2}{*}{$\begin{array}{l}\text { bla } \\
\text { Z }\end{array}$} & \multirow{2}{*}{$\begin{array}{l}\text { van } \\
C\end{array}$} & \multirow{2}{*}{$\begin{array}{l}\text { tet } \\
K\end{array}$} & \multirow{2}{*}{$\begin{array}{l}\text { tet } \\
L\end{array}$} & \multirow{2}{*}{$\begin{array}{l}M s r \\
A / B\end{array}$} & \multicolumn{4}{|c|}{ Ica Genes } & \multirow{2}{*}{ bap } \\
\hline & & & & & & & & $A$ & $B$ & C & $D$ & \\
\hline Sum 1 & cef-str-van-oxa & strong & + & - & - & - & - & + & + & + & + & - \\
\hline Ctrl 2 & cef-str-van-oxa & strong & + & + & + & - & - & + & + & + & + & - \\
\hline XWL2 & cef-str-van-oxa & strong & + & + & + & + & - & + & + & + & + & - \\
\hline RPN4L1 & cef-van-oxa & strong & + & - & - & - & - & - & - & - & - & + \\
\hline RPN4L2 & cef-van-oxa & strong & + & + & - & - & - & + & + & + & - & - \\
\hline RPN21 & cef-oxa-cip-chl & none & - & + & + & + & - & - & - & - & - & + \\
\hline RPN3 & str-van-oxa-tet & strong & + & + & + & + & - & + & + & + & + & - \\
\hline SUM 2 & cef-str-van-oxa & strong & + & - & + & - & - & + & + & + & + & - \\
\hline RPN2L & cef-van-oxa-tet-chl & strong & - & - & - & - & - & + & + & + & + & - \\
\hline RPN1L & cef-van-oxa & strong & + & - & - & - & - & + & - & - & - & - \\
\hline RPN30 & cef-ery-str-van-lev-oxa-tet & strong & + & + & + & + & + & - & + & - & - & - \\
\hline Fa1L & cef-ery-van-oxa-tet & moderate & - & - & + & + & - & - & - & - & - & + \\
\hline $\mathrm{Fa} 2 \mathrm{~S}$ & cef-str-van-sul-lev-oxa-cip-chl & strong & - & - & - & - & - & - & + & - & - & - \\
\hline Bb1LY2 & cef-van-oxa & strong & - & - & - & - & - & - & - & - & - & - \\
\hline LIC3M & cef-van-oxa-cip-chl & strong & + & + & - & - & - & + & + & - & + & - \\
\hline$X Y$ & cef-van-oxa & strong & + & + & + & + & - & - & - & - & - & + \\
\hline LIC 1 & str-van-oxa-tet & strong & - & + & + & + & - & - & - & - & - & + \\
\hline LIC 2M & cef-str-van & strong & - & - & - & - & - & + & + & - & + & - \\
\hline KE18 & cef-oxa-tet & strong & - & - & + & + & + & - & - & - & - & - \\
\hline K5 & cef-van-oxa & strong & + & + & + & + & - & + & + & - & + & - \\
\hline K9 & cef-van-oxa & strong & - & - & - & - & + & + & + & - & + & - \\
\hline K10 & cef-van-oxa & strong & + & - & - & - & - & + & + & - & + & - \\
\hline K11 & cef-van-oxa & strong & + & + & + & + & - & - & + & - & + & - \\
\hline K85 & cef-van-oxa & strong & + & + & - & - & - & + & + & + & + & - \\
\hline K87 & cef-van-oxa & moderate & + & + & - & - & + & + & - & - & + & - \\
\hline
\end{tabular}




\section{Discussion}

S. aureus is an important cause of diseases in both animals and humans $[2,3,6,20]$. The colonization of dairy cattle and subsequent contamination of raw milk by pathogenic $S$. aureus remains an important issue for both the dairy producer and public health [19]. The potential of S. aureus to cause disease is based on its ability to produce a wide variety of virulence factors that contribute to the bacterial invasion [6,19]. Biofilm formation has been reported to enhance the virulence of S. aureus, and strains that form biofilms are more resistant to antibiotics, disinfectants, and other environmental factors [15]. The ica genes play a major role in slime production in S. aureus. It is known that strains harbouring the icaADBC cluster are potential biofilm producers [10]. In addition, the biofilm-associated protein (bap) is vital for the primary attachment of $S$. aureus and biofilm formation [11,12].

In the present study, the genotypic and phenotypic biofilm-producing characteristics of S. aureus isolated from raw unpasteurized and pasteurized milk samples collected from farms and shops in four major localities in the North West Province of South Africa were evaluated. S. aureus was isolated from all $(32,80 \%)$ unpasteurized milk samples, while only 7 out of 24 (29.2\%) pasteurized milk samples showed growth. It is common to observe higher rates of isolation in unpasteurized than in pasteurized milk due to the effect of heat in reducing the microbial load of pasteurized milk. Similar observations have been made in previous studies [14,21]. In a related study, Akindolire and colleagues reported $75 \%$ isolation rate of $S$. aureus from raw milk samples, $29 \%$ from bulk milk samples, and $13 \%$ from pasteurized milk [21]. However, a lower prevalence (22.0\%) of S. aureus in raw milk collected from healthy cows has been reported [28]. It is worth noting that the isolation of S. aureus from $80 \%$ of the milk samples from lactating cows in four prominent farms in the North West Province and in $29.2 \%$ of processed milk meant for human consumption demonstrates the relevance of this pathogen in the region. Besides, more of the isolates $(33,42.9 \%)$ were from samples from Mafikeng. Consequently, further research is necessary to explore methods of controlling $S$. aureus in raw milk, as well as dairy products, in the region.

Phenotypic biofilm production in S. aureus has been extensively studied by using the Congo Red plate assay, which is reported to be highly subjective [29-31], and as a result, microtitre plate assay (MPA) is considerably used as the gold standard for phenotypic biofilm analyses. In the current study, biofilm production was assessed by using the MPA, and it was observed that about $90 \%$ of S. aureus isolates produced biofilms, out of which the majority (66/70, 94.3\%) were classified as "Strong biofilm producers". Similar findings have been previously reported in which most $S$. aureus strains from milk were biofilm producers [31-34]. In one of such studies, all 20 S. aureus strains were biofilm producers and 11 out of 20 (55\%) were classified as strong biofilm producers [33]. In another recent study in Egypt, $69.8 \%$ of $S$. aureus from clinical specimens were biofilm producers; however, contrary to our findings, most $(16 / 43,37.2 \%)$ of their isolates demonstrated weak biofilm production [15]. The discrepancies in the categorization of the biofilm phenotypes could result from differences in the interpretation of results. As such, the standardization of the methods and interpretation of biofilm formation is crucial.

In this study, ica genes (icaA, icaB, icaC, and icaD) were detected among $75.3 \%$ of $S$. aureus isolates, among which icaA was the most prevalent $(49,63.6 \%)$. Our findings are similar to other reports in which the ica genes were detected in all isolates $[33,34]$. While Gowishankar and colleagues detected the ica genes in $84.13 \%$ of S. aureus isolates in India [35], Avila-Novoa detected the genes in $52.3 \%$ of isolates in Brazil [29]. However, the proportion (4,5.1\%) of isolates possessing the $i c a A$ and $i c a D$ genes associated with slime formation was relatively low in this study, as compared with some previous studies $[31,33,34]$. These results suggest that strains of $S$. aureus may present with different capacities to form biofilms based on their source (human or animals) and geographical origin. Further studies, including varied sources, are needed to fully clarify this assertion.

In line with other studies [31,33], results from this study showed that the incidence of the bap gene was low $(12,15.6 \%)$. This might indicate that the ica-dependent mechanism may be primarily responsible for the adhesion and biofilm formation in these isolates, although not all genes responsible for biofilm formation were tested. Despite the pro-biofilm production role of the ica gene, coupled with 
the fact that other possible biofilm-producing genes may be harboured by stains displaying moderate or no biofilm traits, it is recommended that these isolates should be screened for the presence of the $m e c A, f e m A, g y r A, g y r B, g r l A, c f r, \operatorname{erm} A, \operatorname{erm} B$, and erm $C$ genes. However, contrary to our reports, the study by $\mathrm{Li}$ et al. reported that the bap gene was detected in $43.9 \%$ of biofilm-positive $S$. aureus strains, confirming the importance of the bap gene in biofilm formation [36].

Interestingly, our cluster analysis revealed that the predominant genotype (A1a) consists of strains that possess all the four ica genes. This confirms the importance of the ica genes in biofilm formation. In addition, the majority of the isolates that possessed the bap genes did not have the ica genes; suggestive of an ica-bap gene independent mechanism. Although none of the biofilm genes tested were detected in some $(14.3 \%)$ of the isolates, the expression of biofilm formation in these isolates could be mediated by other genes. Generally, the biofilm genes were more common in biofilm-producing isolates than in non-biofilm-producing isolates. These results are concurrent with previous reports [34,36]. The screening of milk for the detection of biofilm-related genes and biofilm-producing Staphylococcus species is important because biofilm facilitates the adhesion to glandular breast tissue and biomaterials, thereby enhancing the bacterial virulence [6,20]. In addition, the presence of biofilms confers resistance of the bacterial community to antibiotics, hence complicating treatment [19].

The misuse and or overuse of antibiotics in livestock is known to have contributed tremendously to the emergence of resistance strains. Antibiotic usage in food-producing animals tend to be increasing worldwide, and in South Africa, two-thirds of antibiotics are administered through animal feed [13]. Previous data have shown that even the antibiotics which are banned in other countries, such as growth promoters, were still being used in South Africa [37]. Consequently, the screening of animal products for antimicrobial resistant pathogens is pertinent. In this study, thirteen antibiotics belonging to nine classes of antimicrobials were screened against $S$. aureus isolated from raw and pasteurized cattle milk, and resistance was observed against all the antibiotics. However, the highest resistance was against ceftriaxone, vancomycin, and penicillin G. High resistance was also observed against other penicillins, such as amoxicillin, ampicillin, ampicillin, and oxacillin. Some of these antibiotics are registered in South Africa as stock remedies-readily available for use by the lay public [16,37]. This could explain the high resistance observed against these antibiotics in our study. Although cephalosporins are rarely used in poultry, the high resistance to ceftriaxone observed in this study may be due to the transfer of a multidrug-resistant plasmid, or to extended-spectrum beta-lactamase (ESBL) production. In this study, vancomycin showed a high resistance of $83.1 \%$. The mechanism of resistance to glycopeptides is not well defined, but it is suggested that resistance could be through the acquisition of the mobile genetic elements of vancomycin-resistant Enterococcus that cause changes in the metabolism and cell wall of Staphylococcus [38]. These results are in line with reports from previous studies on animal and clinical samples $[22,33,39,40]$. Ateba and colleagues recorded a moderate to high percentage (39-100\%) of resistance to methicillin, ampicillin, penicillin G, sulfamethoxazole, oxytetracycline, and erythromycin among $S$. aureus isolates from communal farms [22].

Five resistance genes, blaZ, vanB, tet $K$, tet $L$, and $m s r A$, were equally detected in our isolates, in relatively high proportions. However, the distribution of these genes with respect to phenotypic antibiotic resistance was not statistically significant. This is contrary to studies by Zehra et al. which reported a statistically significant relationship between phenotypes and genotype resistance pattern in $S$. aureus strains [40]. The phenotypic resistance in strains without the genes may be caused by other attributes, such as point mutations, biofilm formation, or antibiotic tolerance. The van $A$ and mefA genes were not detected in this study, and this is similar to previous reports [41].

In this study, the diameter of the zone of inhibition of penicillin (PD) was higher in S. aureus isolates without the blaZ gene than those with the blaZ gene. In a similar study, Ferreira et al. reported that $S$. aureus isolates with a penicillin diameter less than $28 \mathrm{~mm}$ carried the blaZ gene [42]. However, a large inhibition halo did not rule out the presence of the blaZ gene, as reported by other colleagues [43,44]. These reports suggested that changing the breakpoint of the penicillin inhibition halo from 29 to $35 \mathrm{~mm}$ would improve sensitivity of the test. Moreover, our results revealed a relationship between blaZ and 
beta lactamase production, with more $(25 / 29,86.2 \%)$ of the isolates positive for the blaZ gene also expressing beta lactamase production. Meanwhile, $56(72.7 \%)$ of the isolates were positive for beta lactamase production by the zone-edge test. Similar results have been reported in which Marques et al. recorded a $100 \%$ positive zone-edge test among S. aureus isolates from bovine mastitis [33].

\section{Materials and Methods}

\subsection{Study Site}

This study was conducted in the North-West University, Mafikeng, South Africa. Milk samples were collected from dairy farms and shops in Lichtenburg, Mafikeng, and Zeerust, which are all located in the Northwest Province of South Africa. Laboratory analyses were performed in the Molecular Microbiology Laboratory of the Department of Biological Sciences.

\subsection{Sample Collection}

Unpasteurized milk samples were collected directly from dairy cattle, as well as from storage tanks in various farms, while pasteurized milk was bought from shops. The samples were transported on ice to the laboratory, for analysis. A total of 64 milk samples were obtained, and out of these samples, 40 were unpasteurized, while 24 were pasteurized.

\subsection{Isolation and Identification of Staphylococcus aureus Isolates}

A ten-fold serial dilutions of each milk sample was performed, using sterile $2 \%(\mathrm{w} / \mathrm{v})$ peptone water (Biolab, South Africa). An aliquot of $100 \mu \mathrm{L}$ of the diluted milk was spread-plated on mannitol salt agar (MSA) (Merck, Darmstadt, Germany), and the plates were incubated aerobically at $37^{\circ} \mathrm{C}$ for $24 \mathrm{~h}$. Isolates that presented with yellow colonies were subcultured on MSA, and the plates were incubated aerobically at $37^{\circ} \mathrm{C}$ for $24 \mathrm{~h}$. Pure colonies were identified by using standard biochemical tests (cellular morphology, catalase test, coagulase test, and mannitol fermentation). All catalase positive, coagulase positive, and Gram-positive cocci in clusters that fermented mannitol were stored in Tryptic soy broth with $40 \%(\mathrm{v} / \mathrm{v})$ glycerol, at $-80^{\circ} \mathrm{C}$, for further analyses. DNA was extracted from the isolates, using the Zymo Research Genomic DNA ${ }^{\mathrm{TM}}$ Tissue MiniPrep Kit (Inqaba Biotec, Pretoria, South Africa), and confirmation of $S$. aureus isolates was done by PCR, using the nuc gene primers (Table 1). The reactions were prepared in $25 \mu \mathrm{L}$ volumes made up of $12.5 \mu \mathrm{L}$ of One Taq ${ }^{\mathrm{R}}$ Quickload $2 \mathrm{X}$ Master Mix with standard buffer (Biolabs, New England, UK), $0.25 \mu \mathrm{L}$ of each primer, $1 \mu \mathrm{L}$ of template DNA, and $11 \mu \mathrm{L}$ nuclease-free sterile water. Amplifications were performed by using the modelBio-Rad C1000 Touch ${ }^{\mathrm{TM}}$ Thermal Cycler (Bio-Rad Laboratories, Inc., Hercules, California, USA). PCR conditions comprised an initial denaturation at $94{ }^{\circ} \mathrm{C}$ for $5 \mathrm{~min}$, followed by 35 cycles of denaturation at $94{ }^{\circ} \mathrm{C}$ for $30 \mathrm{~s}$, annealing at $55^{\circ} \mathrm{C}$ for $30 \mathrm{~s}$, and extension at $72{ }^{\circ} \mathrm{C}$ for $1 \mathrm{~min}$. A final extension step was performed at $72{ }^{\circ} \mathrm{C}$ for $10 \mathrm{~min}$. PCR products were stored at $4{ }^{\circ} \mathrm{C}$, until electrophoresis. All PCR reagents were Fermentas products (Thermo Fisher Scientific Inc., Waltham, MA, USA) obtained from Inqaba Biotec Ltd., South Africa.

\subsection{PCR Detection of Biofilm and Antimicrobial Resistance Genes}

All isolates confirmed to be $S$. aureus by the presence of the $n u c$ gene were screened for the presence of biofilm genes (icaA, icaB, icaC, icaD, and bap) and resistance genes (blaZ, vanB, tet $K$, tet $L$, and $m s r A / B$ ); primer sequences are presented in Table 5 . The reactions were prepared in $25 \mu \mathrm{L}$ volumes made up of $12.5 \mu \mathrm{L}$ of One Taq ${ }^{\mathrm{R}}$ Quickload 2X Master Mix with standard buffer (Biolabs, New England, UK), $1 \mu \mathrm{L}$ of template DNA, and a final primer concentration of $0.2 \mu \mathrm{M}$. Amplifications were performed by using the model Bio-Rad C1000 Touch ${ }^{\mathrm{TM}}$ Thermal Cycler (Bio-Rad Laboratories, Inc., Hercules, California, USA). The PCR conditions were the same as those for the $n u c$ gene, except for blaZ and tet $L$ genes, which annealed at $50{ }^{\circ} \mathrm{C}$. All PCR products were resolved by electrophoresis on a $1 \%(\mathrm{w} / \mathrm{v})$ agarose gel, at 80 volts, for $3 \mathrm{~h}$, using 1 X TAE buffer ( $40 \mathrm{mM}$ Tris, $1 \mathrm{mM}$ EDTA, and $20 \mathrm{mM}$ glacial acetic 
acid, pH 8.0). A 100 bp DNA molecular weight marker (Thermo Fisher Scientific Inc., Waltham, MA, USA) was included in each gel. The gels were stained in $0.001 \mu \mathrm{g} / \mathrm{mL}$ of ethidium bromide, for $15 \mathrm{~min}$, and the amplicons were visualized, using a Bio-RAD ChemiDoc ${ }^{\mathrm{TM}}$ MP Imaging System (Bio-Rad Laboratories Ltd., Watford, UK).

Table 5. Putative virulence and resistance genes and primer sequences used in this study.

\begin{tabular}{|c|c|c|c|}
\hline Gene & Primer Sequence & Amplicon Size (bp) & Reference \\
\hline nuc & $\begin{array}{l}\text { F-GCGATTGATGGTGGATACGGT } \\
\text { R-AGCCAAGCCTTGACGAACTAAAGC }\end{array}$ & 279 & [45] \\
\hline$i c a A$ & $\begin{array}{l}\text { F-ACACTTGCTGGCGCAGTCAA } \\
\text { R-TCTGGAACCAACATCCAACA }\end{array}$ & 188 & [46] \\
\hline$i c a B$ & $\begin{array}{l}\text { F-AGAATCGTGAAGTATAGAAAATT } \\
\text { R-TCTAATCTTTTTCATGGAATCCGT }\end{array}$ & 900 & [46] \\
\hline$i c a C$ & $\begin{array}{l}\text { F-ATGGGACGGATTCCATGAAAAAGA } \\
\text { R-TAATAAGCATTAATGTTCAATT }\end{array}$ & 1075 & [46] \\
\hline$i c a D$ & $\begin{array}{l}\text { F-ATGGTCAAGCCCAGACAGAG } \\
\text { R-AGTATTTTCAATGTTTAAAGCAA }\end{array}$ & 198 & [46] \\
\hline bap & $\begin{array}{l}\text { F-CCCTATATCGAAGGTGTAGAATTGCAC } \\
\text { R-GCTGTTGAAGTTAATACTGTACCTGC }\end{array}$ & 971 & [11] \\
\hline blaZ & $\begin{array}{l}\text { F-CAAAGATGATATAGTTGCTTATTCTCC } \\
\text { R-TGCTTGACCACTTTTATCAGC }\end{array}$ & 421 & [43] \\
\hline tetK & $\begin{array}{l}\text { F-GTAGCGACAATAGGTAATAGT } \\
\text { R-GTAGTGACAATAAACCTCCTA }\end{array}$ & 360 & [47] \\
\hline tet $L$ & $\begin{array}{l}\text { F-GTCGTTGCGCGCTATATTCC } \\
\text { R-GTGAACGGTAGCCCACCTAA }\end{array}$ & 696 & [48] \\
\hline mefA & $\begin{array}{l}\text { F-AGTATCATTAATCACTAGTGC } \\
\text { R-TTCTTCTGGTACAAAAGTGG }\end{array}$ & 367 & [49] \\
\hline$m s r A$ & $\begin{array}{l}\text { F-CGATGAAGGAGGATTAAAATG } \\
\text { R-CATGAATAGATTGTCCTGTTAATT }\end{array}$ & 1733 & [49] \\
\hline vanA & $\begin{array}{l}\text { F-ATGAATAGAATAAAAGTTGC } \\
\text { R-TCACCCCTTTAACGCTAATA }\end{array}$ & 1032 & {$[50]$} \\
\hline $\operatorname{van} B$ & $\begin{array}{l}\text { F-GTGACAAACCGGAGGCGAGGA } \\
\text { R-CCGCCATCCTCCTGCAAAAAA }\end{array}$ & 430 & [51] \\
\hline
\end{tabular}

\subsection{Phenotypic Biofilm Production}

Formation of biofilm by $S$. aureus was evaluated by using a modified version of the microtitre plate (MTP) test described by Christensen et al. [52]. Overnight cultures of the bacterial isolates were diluted 1:1 in Tryptic soy broth. Each well (of a 96-well plate) was filled with $200 \mathrm{uL}$ of the diluted culture. The plates were incubated for $24 \mathrm{~h}$ at $37^{\circ} \mathrm{C}$, after which the wells were washed three times with $200 \mathrm{uL}$ of phosphate buffer saline (PBS), $\mathrm{pH}$ 7.2. The plates were dried at room temperature for $1 \mathrm{~h}$. The wells were stained by adding $200 \mathrm{uL}$ of $1 \%$ crystal violet for one minute, after which excess dye was removed and the wells were rinsed three times with PBS. The optical density was read, using the MB-580 Microtitre plate reader (Heales Technology, Shenzhen, China), at a wavelength of $680 \mathrm{~nm}$. Interpretation of results was done as previously described [36], and results were recorded as none, weak, moderate, and strong biofilm-producing.

\subsection{Antibiotic Susceptibility Testing (AST)}

All S. aureus isolates were screened for susceptibility to the following antimicrobial agents: oxacillin $(1 \mu \mathrm{g})$, erythromycin $(15 \mu \mathrm{g})$, vancomycin $(30 \mu \mathrm{g})$, streptomycin $(10 \mu \mathrm{g})$, tetracycline $(30 \mu \mathrm{g})$, levofloxacin $(5 \mu \mathrm{g})$, sulfamethoxazole-trimethoprim $(25 \mu \mathrm{g})$, ciprofloxacin $(5 \mu \mathrm{g})$, penicillin (10 Units), chloramphenicol $(30 \mu \mathrm{g})$, amoxicillin $(10 \mu \mathrm{g})$, ceftriaxone $(30 \mu \mathrm{g})$, and ampicillin $(10 \mu \mathrm{g})$, by the disk diffusion technique. Suspensions of overnight cultures were prepared and diluted, using sterile normal saline, to obtain the inoculum that was compared with a $0.5 \mathrm{McFarland}$ 's standard. The inoculum was plated on Mueller Hinton agar (Merck, Darmstadt, Germany) and incubated at $37^{\circ} \mathrm{C}$ for $18-24 \mathrm{~h}$. 
The zones of inhibition were measured, and the results were interpreted based on recommended standards $[53,54]$.

\subsection{Phenotypic Evaluation of Beta-Lactamase Production and Inducible Clindamycin Resistance}

The zone-edge test was used to evaluate beta-lactamases production by isolates. Procedures were carried out as previously described [42]. Bacterial inoculum was plated on MHA, and penicillin-G disks (10 Units) were placed at the centre of each plate, and the plates were incubated as in AST described above. The zones of inhibition were observed and results were recorded as follows: Positive-zones with sharp edge; Negative—zones with fuzzy edge.

The Double diffusion (D-test) was used to detect isolates with inducible clindamycin resistance, and procedures were done as described [55]. Bacterial inoculum was plated as in the disk diffusion method. Erythromycin $(15 \mu \mathrm{g})$ and Clindamycin $(2 \mu \mathrm{g})$ disks were placed edge-to-edge on the agar plate, at a distance of about $15 \mathrm{~mm}$. The plates were incubated overnight; after that, they were observed for a flat zone of inhibition.

\subsection{Statistical Analysis}

Data was analysed by using the SPSS version 20 (SPSS, Chicago, USA) statistical package. Descriptive statistic was done for all variables, and the Chi square test was used to determine significant differences between categorical variables, while the Mann-Whitney U test was used to compare means at a $95 \%$ confidence level.

\section{Conclusions}

The ica and bap genes were detected in S. aureus isolated from milk. The presence of these genes in biofilm-producing isolates indicates their importance in biofilm formation in $S$. aureus. High resistance against ceftriaxone, vancomycin, and penicillin, as well as five different resistance genes, were detected among these isolates. The presence of potential biofilm-producing and antibiotic-resistant S. aureus in milk intended for human consumption may present with severe health challenges. Consequently, there is a need to enhance control measures, especially in the dairy sector, to curb the spread of pathogenic S. aureus and to limit the use of antibiotics.

Author Contributions: M.E.A.B., design of methodology, sample collection and laboratory analysis, data validation, and writing and revision of the manuscript; C.N.A., conception and design of the study, funding acquisition, project administration, resources, data validation, and revision and final approval of the manuscript. All authors have read and agreed to the published version of the manuscript.

Funding: This research was funded by the Postdoctoral Fellowship program of the North-West University, South Africa.

Acknowledgments: We are grateful to the Department of Microbiology, North-West University, Mafikeng Campus for providing the facilities where the study was conducted. We also acknowledge the support of the owners and workers of the farms where the samples were collected.

Conflicts of Interest: The authors declare no conflict of interest.

\section{References}

1. Kloos, W.E. Natural populations of the genus Staphylococcus. Annu. Rev. Microbiol. 1980, 34, 559-592. [CrossRef]

2. Foster, T.J. Staphylococcus aureus. In Molecular Medical Microbiology, 2nd ed.; Sussmann, M., Newcastle, U.T., Eds.; Academic Press: Cambridge, MA, USA, 2002; pp. 839-888.

3. Hermans, K.; Devriese, L.A.; Haesebrouck, F. Staphylococcus. In Pathogenesis of Bacterial Infections in Animals, 3rd ed.; Gyles, C.L., Songer, J.G., Thoen, C.O., Eds.; Blackwell Publishing: Hoboken, NJ, USA, 2004; pp. 43-56.

4. Marshall, B.M.; Levy, S.B. Food animals and antimicrobials: Impacts on human health. Clin. Microbiol. Rev. 2011, 24, 718-733. [CrossRef] [PubMed]

5. Le Loir, Y.; Baron, F.; Gautier, M. Staphylococcus aureus and food poisoning. Gen. Mol. Res. 2003, 2, 63-76. 
6. Ferry, T.; Perpoint, T.; Vandenesch, F.; Etienne, J. Virulence determinants in Staphylococcus aureus and their involvement in clinical syndromes. Curr. Infect. Dis. Rep. 2005, 7, 420-428. [CrossRef] [PubMed]

7. Otto, M. Staphylococcal biofilms. Curr. Top. Microbiol. Immunol. 2008, 322, 207-228. [PubMed]

8. Periasamy, S.; Joo, H.-S.; Duong, A.C.; Bach, T.-H.L.; Tan, V.Y.; Chatterjee, S.S.; Cheung, G.Y.C.; Otto, M. How Staphylococcus aureus biofilms develop their characteristic structure. PNAS 2012, 109, 1281-1286. [CrossRef] [PubMed]

9. McKenney, D.; Ubner, J.H.; Muller, E.; Wang, Y.; Goldmann, D.A.; Pier, G.B. The ica locus of Staphylococcus epidermidis encodes production of the capsular polysaccharide/adhesion. Infect. Immun. 1998, 66, 4711-4720. [CrossRef]

10. Atshan, S.S.; Nor Shamsudin, M.; Sekawi, Z.; Lung, L.; Hamat, R.A.; Karunanidhi, A.; Ali, A.M.; Ghaznavi-Rad, E.; Moghaddam, H.G.; Seng, J.S.C.; et al. Prevalence of adhesion and regulation of biofilm-related genes in different clones of Staphylococcus aureus. J. Biomed. Biotech. 2012, 2012, 1-10.

11. Cucarella, C.; Tormo, M.A.; Ubeda, C.; Trotonda, M.P.; Monzón, M.; Peris, C.; Amorena, B.; Lasa, I.; Penadés, J.R. Role of biofilm-Associated protein bap in the pathogenesis of bovine Staphylococcus aureus. Infect. Immun. 2004, 72, 2177-2185. [CrossRef]

12. Lassa, I.; Penades, J.R. A family of surface proteins involved in biofilm formation. Res. Microbiol. 2006, 157, 99-107. [CrossRef]

13. Garcés, L. The Detrimental Impacts of Industrial Animal Agriculture: A Case for Humane and Sustainable Agriculture, Compassion in World Farming Trust. 2002. Available online: http://www.ciwf.org.uk/ includes/documents/cm_docs/2008/d/detrimental_impact_industrial_animal_agriculture_2002.pdf (accessed on 12 January 2020).

14. Girardini, L.K.; Paim, D.S.; Ausani, T.C.; Lopes, G.V.; Pellegrini, D.C.P.; Brito, M.A.V.P.; Cardoso, M. Antimicrobial resistance profiles of Staphylococcus aureus clusters on small dairy farms in southern Brazil. Pesq. Vet. Bras. 2016, 36, 951-956. [CrossRef]

15. Neopane, P.; Nepal, H.P.; Hrestha, R.; Uehara, O.; Abiko, Y. In vitro biofilm formation by Staphylococcus aureus isolated from wounds of hospital-admitted patients and their association with antimicrobial resistance. Int. J. Gen. Med. 2018, 11, 25-32. [CrossRef] [PubMed]

16. Henton, M.M.; Eagar, H.A.; Swan, G.E.; van Vuuren, M. Antibiotic management and resistance in livestock production. S. Afr. Med. J. 2011, 101, 583-586. [PubMed]

17. Lim, D.; Strynadka, N.C. Structural basis for the ß-lactam resistance of PBP2a from methicillin-Resistant Staphylococcus aureus. Nat. Struct. Mol. Biol. 2002, 9, 870-876.

18. Juhász-Kaszanyitzky, E.; Jánosi, S.; Somogyi, P.; Dán, A.; Bloois, L.G.; Van Duijkeren, E.; Wagenaar, J.A. MRSA transmission between cows and humans. Emerg. Infect. Dis. 2007, 13, 630-632. [CrossRef]

19. Cosgrove, S.E. The relationship between antimicrobial resistance and patient outcomes: Mortality, length of hospital stay, and health care costs. Genet. Mol. Res. 2006, 42, S82-S89. [CrossRef]

20. Lowy, F. Staphylococcal infections. In Harrison's Principles of Internal Medicine; Fauci, A., Braunwald, E., Casper, D., Hauser, S., Longo, D., Jameson, J., Eds.; The McGraw-Hill Companies Inc.: New York, NY, USA, 2013; pp. 386-399.

21. Akindolire, M.A.; Babalola, O.O.; Ateba, C.N. Detection of antibiotic resistant Staphylococcus aureus from milk: A public health implication. Int. J. Environ. Res. Public Health. 2015, 12, 10254-10275. [CrossRef]

22. Ateba, C.N.; Mbewe, M.; Moneoang, M.S.; Bezuidenhout, C.C. Antibiotic-resistant Staphylococcus aureus isolated from milk in the Mafikeng Area, North West province, South Africa. S. Afr. J. Sci. 2010, 106. [CrossRef]

23. Schmidt, T.; Kock, M.M.; Ehlers, M.M. Molecular characterization of Staphylococcus aureus isolated from bovine mastitis and close human contacts in south african dairy herds: Genetic diversity and inter-species host transmission. Front. Microbiol. 2017, 8, 1-15. [CrossRef]

24. Lochem, S.V.; Thompson, P.N.; Annandale, C.H. Prevalence of MRSA among large commercial pig herds in South Africa. Onderstepoort J. Vet. Res. 2018, 85, 1-4.

25. Akanbi, O.E.; Njom, H.A.; Fri, J.; Otigbu, A.C.; Clarke, A.M. Antimicrobial susceptibility of Staphylococcus aureus isolated from recreational waters and beach sand in eastern cape province of South Africa. Int. J. Environ. Res. Public Health. 2017, 14, 1001. [CrossRef] [PubMed] 
26. Fortuin-de Smidt, M.C.; Singh-Moodley, A.; Badat, R.; Quan, V.; Kularatne, R.; Nana, T.; Lekalaka, R.; Govender, N.P.; Perovic, O. Staphylococcus aureus bacteraemia in Gauteng academic hospitals, South Africa. Int. J. Infect. Dis. 2015, 30, 41-48. [CrossRef] [PubMed]

27. Naicker, P.R.; Karayem, K.; Hoek, K.G.; Harvey, J.; Wasserman, E. Biofilm formation in invasive Staphylococcus aureus isolates is associated with the clonal lineage. Microb. Pathog. 2016, 90, 41-49. [CrossRef] [PubMed]

28. Liu, H.; Li, S.; Meng, L.; Dong, L.; Zhao, S.; Lan, X.; Wang, J.; Zheng, N. Prevalence, antimicrobial susceptibility, and molecular characterization of Staphylococcus aureus isolated from dairy herds in northern China. J. Dairy Sci. 2017, 100, 8796-8803. [CrossRef] [PubMed]

29. Avila-Novoa, M.G.; Iñıguez-Moreno, M.; Solıs-Velazquez, O.A.; Gonzalez-Gomez, J.P.; Guerrero-Medina, P.J.; Gutierrez-Lomel, M. Biofilm Formation by Staphylococcus aureus isolated from Food Contact Surfaces in the Dairy Industry of Jalisco, Mexico. J. Food Qual. 2018, 1746139. [CrossRef]

30. Nourbakhsh, F.; Namvar, A.E. Detection of genes involved in biofilm formation in Staphylococcus aureus isolates. GMS Hyg. Infect. Control 2016, 11. [CrossRef]

31. Szweda, P.; Schielmann, M.; Milewski, S.; Jakubczak, A.; Frankowska, A. Biofilm production and presence of ica and bap genes in Staphylococcus aureus strains isolated from cows with Mastitis in the Eastern Poland. Pol. J. Microbiol. 2012, 61, 65-69. [CrossRef]

32. Begum, H.A.; Uddin, M.S.; Islam, M.J.; Nazir, K.H.; Islam, M.A.; Rahman, M.T. Detection of biofilm producing coagulase positive Staphylococcus aureus from bovine mastitis, their pigment production, hemolytic activity and antibiotic sensitivity pattern. J. Bangladesh Soc. Agric. Sci. Technol. 2007, 4, 97-100.

33. Marques, V.F.; Motta, C.C.; Soares, B.S.; Melo, D.A.; Coelho, S.M.O.; Coelho, I.S.; Barbosa, H.S. Biofilm production and beta-lactamic resistance in Brazilian Staphylococcus aureus isolates from bovine mastitis. Braz. J. Microbiol. 2017, 48, 118-124. [CrossRef]

34. Wang, W.; Lin, X.; Jiang, T.; Peng, Z.; Xu, J.; Yi, L.; Li, F.; Fanning, S.; Baloch, Z. Prevalence and Characterization of Staphylococcus aureus Cultured From Raw Milk Taken From Dairy Cows With Mastitis in Beijing, China. Front. Microbiol. 2018, 9, 11-23. [CrossRef]

35. Gowrishankar, S.; Kamaladevi, A.; Balamurugan, K.; Pandian, S.K. In Vitro and In Vivo Biofilm Characterization of Methicillin-Resistant Staphylococcus aureus from Patients Associated with Pharyngitis Infection. BioMed Res. Int. 2016, 2016, 1289157. [CrossRef]

36. Li, L.; Yang, H.J.; Liu, D.C.; He, H.B.; Wang, C.F.; Zhang, J.F.; Gao, Y.D.; Yangjun, Z. Analysis of biofilm formation and associated genes detected in Staphylococcus isolates from bovine mastitis. Intern. J. Appl. Res. Vet. Med. 2012, 10, 62-68.

37. Eagar, H.; Swan, G.; Van Vuuren, M. A survey of antimicrobial usage in animals in South Africa with specific reference to food animals. J. S. Afr. Vet Assoc. 2012, 83, 8. [CrossRef] [PubMed]

38. Gardete, S.; Tomasz, A. Mechanisms of vancomycin resistance in Staphylococcus aureus. J. Clin. Investig. 2014, 124, 2836-2840. [CrossRef] [PubMed]

39. Bissong, M.E.A.; Wirgham, T.; Enekegbe, M.A.; Niba, P.T.N.; Foka, F.E.T. Prevalence and antibiotic susceptibility patterns of methicillin resistant Staphylococcus aureus in patients attending the Laquintinie Hospital Douala, Cameroon. Eur. J. Clin. Biomed. Sci. 2016, 2, 92-96. [CrossRef]

40. Zehra, A.; Singh, R.; Kaur, S.; Gill, J.P.S. Molecular characterization of antibiotic-resistant Staphylococcus aureus from livestock (bovine and swine). Vet. World 2017, 10, 598-604. [CrossRef]

41. Akpaka, P.E.; Roberts, R.; Monecke, S. Molecular characterization of antimicrobial resistance genes against Staphylococcus aureus isolates from Trinidad and Tobago. J. Infect. Public Health. 2017, 10, 316-323. [CrossRef]

42. Ferreira, A.M.; Martins, K.B.; da Silva, V.R.; Mondelli, A.L.; de Souza da Cunha, M.L.R. Correlation of phenotypic tests with the presence of the blaZ gene for detection of beta-lactamase. Braz. J. Microbiol. 2017, 48, 159-162. [CrossRef]

43. Kaase, M.; Lenga, S.; Friedrich, S.; Szabados, F.; Sakinc, T.; Kleine, B.; Gatermann, S.G. Comparison of phenotypic methods for penicillinase detection in Staphylococcus aureus. Clin. Microbiol. Infect. 2008, 4, 614-616. [CrossRef]

44. El Feghaly, R.E.; Stamm, J.E.; Fritz, S.A.; Burnham, C.D. Presence of the blaZ beta-lactamase gene in isolates of Staphylococcus aureus that appear penicillin susceptible by conventional phenotypic methods. Diagn. Microbiol. Infect. Dis. 2012, 74, 388-393. [CrossRef]

45. Brakstad, O.G.; Aasbakk, K.; Maeland, J.A. Detection of Staphylococcus aureus by polymerase chain reaction amplification of the nuc gene. J. Clin. Microbiol. 1992, 30, 1654-1660. [CrossRef] [PubMed] 
46. Alfatemi, S.M.H.; Motamedifar, M.; Hadi, N.; Ebrahim-Saraie, H.S. Analysis of virulence genes among methicillin resistant Staphylococcus aureus (MRSA) strains. Jundishapur J. Microbiol. 2014, 7, e10741.

47. Strommenger, B.; Kettlitz, C.; Werner, G.; Witte, W. Multiplex PCR assay for simultaneous detection of nine clinically relevant antibiotic resistance genes in Staphylococcus aureus. J. Clin. Microbiol. 2003, 41, 4089-4094. [CrossRef] [PubMed]

48. Huys, G.; D’Haene, K.; Van Eldere, J.; von Holy, A.; Swings, J. Molecular diversity and characterization of tetracycline-resistant Staphylococcus aureus isolates from a poultry processing plant. Appl. Environ. Microbiol. 2005, 71, 574-579. [CrossRef]

49. Ding, Z.F.; Zhang, H.; Tang, W.; Tong, C.Y.; Li, R.T.; Chen, L.X.; Pu, L.J.; Zhu, Z.B.; Cui, Y.D. Methylase genes-mediated erythromycin resistance in Staphylococcus aureus from bovine mastitis in China. Israel J. Vet. Med. 2012, 67, 170-179.

50. Saha, B.; Singh, A.K.; Ghosh, A.; Bal, M. Identification and characterization of a vancomycin-resistant Staphylococcus aureus isolated from Kolkata (South Asia). J. Med. Microbiol. 2008, 57, 72-79. [CrossRef]

51. Saadat, S.; Solhjoo, K.; Norooz-Nejad, M.J.; Kazemi, A. VanA and vanB positive vancomycin-resistant Staphylococcus aureus among clinical isolates in Shiraz, South of Iran. Oman Med. J. 2014, 29, 335. [CrossRef] [PubMed]

52. Christensen, G.D.; Simpson, W.A.; Younger, J.J.; Baddour, L.M.; Barrett, F.F.; Melton, D.M.; Beachey, E.H. Adherence of coagulase-negative staphylococci to plastic tissue culture plates: A quantitative model for the adherence of staphylococci to medical devices. J. Clin. Microbiol. 1985, 22, 996-1006. [CrossRef]

53. Clinical and Laboratory Standards Institute (CLSI). Performance Standards for Antimicrobial Susceptibility Testing, 26th ed.; CLSI supplement M100S; Wayne, P.A., Ed.; Clinical and Laboratory Standards Institute: West Valley Road, PA, USA, 2016.

54. Clinical and Laboratory Standards Institute (CLSI). Performance Standards for Antimicrobial Disk and Dilution Susceptibility Tests for Bacteria Isolated from Animals, 3rd ed.; CLSI document M31-A3; Clinical and Laboratory Standards Institute: Wayne, PA, USA, 2008; ISBN 1-56238-659-X.

55. Ghanbari, F.; Ghajavand, H.; Havaei, R.; Jami, M.-S.; Khademi, F.; Heydari, L.; Shahin, M.; Havaei, S.A. Distribution of erm genes among Staphylococcus aureus isolates with inducible resistance to clindamycin in Isfahan, Iran. Adv. Biomed. Res. 2016, 5, 62. [CrossRef] 